\title{
Pengaruh Penjualan Online di masa Pademi Coviv-19 terhadap UMKM Menggunakan metode Wawancara
} (Studi Kasus UKM Salad Nyoo Timoho Yogyakarta)

\author{
Agus Dwi Cahya \\ Universitas Sarjanawiyata Tamansiswa \\ agusdc@ustjoga.ac.id

\section{Aminah \\ Universitas Sarjanawiyata Tamansiswa aminahustjogjaekonomi@gmail.com}

\section{Atma Fadna Rinaja}

Universitas Sarjanawiyata Tamansiswa atmharinataaa@gmail.com

\section{Nadya Adelin}

Universitas Sarjanawiyata Tamansiswa nandersvin88@gmail.com
Abstrak
Tepat sudah setahun Pandemi Covid-19 merubah tatanan kehidupan masyarakat Indonesia. Segala aktivitas dilakukan secara online ataupun daring guna menghindari berkumpulnya manusia. Tentu saja ini keadaan sangat berdampak di perekonomian Indonesia khususnya pada UMKM. Penurunan omzet para pelaku UMKM sangat signifikan termasuk juga lapangan usaha penyedia makanan dan minuman. Penjualan online menjadi strategi juga sarana pendongkrak kehidupan ekonomi di masa pandemi. Penelitian ini bertujuan untuk mengetahui seberapa besar pengaruh dari penjualan online selama masa Pandemi Covid-19 terhadap UKM Salad Nyoo Timoho. Metode untuk mendapatkan data dalam penelitian ini adalah pendekatan kualitatif dengan wawancara secara langsung dengan narasumber yaitu pelaku usaha Salad Nyoo Timoho dan juga analisis SWOT. Pada masa pandemi ini UMKM sangatlah berpengaruh karena dapat menstabilkan perekonomian Indonesia. Kolaborasi oleh UMKM dengan bekerja sama dengan platform, marketplace dan media social sangat membantu sebagai media pemasaran, promosi dan penjualan online.

Kata Kunci dampak pandemi covid-19, penjualan online, omzet, UMKM

\section{PENDAHULUAN}

Tidak terasa sudah satu tahun telah berlalu dan masih mengakibatkan banyak perubahan di tatanan kehidupan masyarakat, tidak hanya di Indonesia tetapi juga ke seluruh dunia dengan cepat. Hal ini terjadi karena adanya pandemi Covid-19. Sejak 11 


\section{JESYA}

JURNAL EKONOMI \& EKONOMI SYARIAH

Jurnal Ekonomi \& Ekonomi Syariah Vol 4 No 2, Juni 2021

E-ISSN : 2599-3410 | P-ISSN : 2614-3259

DOI : https://doi.org/10.36778/jesya.v4i2.407

Maret 2020, WHO (World Health Organization) telah resmi mengumumkan virus corona sebagai pandemi dunia. Pernyataan pandemi tersebut didasarkan atas tingkat penyebaran wabah yang tak terkendali ke berbagai negara di dunia. Pandemi diumumkan tidak hanya sebagai peringatan atas kesiapsiagaan kebutuhan medis melainkan kesiapsiagaan atas berbagai aspek yang akan terpengaruh. Untuk mencegah semakin banyak penularan virus Covid-19 ini, pemerintah telah mengeluarkan berbagai kebijakan secara masif. Dampak dari Covid-19 berpengaruh pada beberapa sektor di Indonesia yaitu sektor kesehatan, ekonomi, pendidikan dan masih banyak lagi. Dalam penelitian ini, membahas secara khusus dalam sektor ekonomi.

Pembangunan dan perkembangan perekonomian negara - negara berkembang seperti Indonesia sangat bergantung pada UMKM. Hal ini dikarenakan "usaha mikro, kecil dan mengengah" ini banyak menyerap tenaga kerja dan sangat produktif berkontribusi sehingga berdampak pada berkurangnya jumlah pengangguran dan dapat meningkatkan pendapatan per kapita suatu negara. Berdasarkan data yang diolah P2E LIPI, dampak penurunan pariwisata terhadap UMKM yang bergerak dalam usaha makanan dan minuman mikro mencapai 27\%. Sedangkan dampak terhadap usaha kecil makanan dan minuman sebesar $1,77 \%$, dan usaha menengah di angka $0,07 \%$. Pengaruh virus Covid-19 terhadap unit kerajinan dari kayu dan rotan, usaha mikro akan berada di angka 17,03\%. Untuk usaha kecil di sektor kerajinan kayu dan rotan $1,77 \%$ dan usaha menengah $0,01 \%$. Sementara itu, konsumsi rumah tangga juga akan terkoreksi antara 0,5\% hingga $0,8 \%$. Menurut Febrantara (2020) dan OECD (2020), dari sisi penawaran dan sisi permintaan dapat terlihat dampak langsung dari Covid-19 terhadap UMKM. Dilihat dari sisi penawaran, karena pandemi, banyak sekali UMKM yang mengalami kurangnya tenaga kerja, alasannya yaitu karena menjaga kesehatan pekerja dan adanya pemberlakuan pembatasan sosial (social distancing) sehingga masyarakat enggan untuk bekerja sementara waktu. Dilihat dari sisi permintaan, berkurangnya permintaan barang dan jasa berdampak pada UKM karena tidak dapat menjalankan usaha dengan optimal sehingga menyebabkan masyarakat sulit menghasilkan pendapatan, karena UKM tidak mampu untuk membayar hak upah pekerja, maka berujung pada pemutusan hubungan kerja secara sepihak.

UMKM industri makanan dan minuman adalah bisnis yang tidak mengenal masa dan tidak pernah mati. Bisnis makanan dan minuman selalu saja ada di setiap wilayah atau tempat, untuk berbagai usia dan kelas masyarakat selalu membutuhkan makanan dan minuman, dari yang berskala besar ataupun kecil. Namun, pertumbuhan industri makanan dan minuman sedikit mengalami hambatan akibat pandemi Covid-19 yang terus berlangsung. Banyak UKM yang gulung tikar atau tutup akibat dari pembatasan aktivitas masyarakat selama pandemi sehingga mempengaruhi penghasilan yaitu penurunan omzet usaha. Meskipun begitu, dari beberapa sektor usaha, industri makanan dan minuman ini lah yang cukup mampu bertahan menghadapi pandemi. Dengan digital marketing atau juga penjualan online, para pelaku usaha memanfaatkan peluang tersebut.

Beberapa penelitian yang berhubungan dengan pengaruh penjualan online dimasa pandemi Covid-19, diantaranya Thaha (2020) tentang dampak Covid-19 terhadap UMKM di Indonesia, yang hasilnya yaitu para pengusaha melihat pada masa pandemi Covid-19 terdapat kebutuhan baru untuk mengurangi efek negatif akibat krisis Covid-19 yaitu pada perubahan digital. UMKM dapat beradaptasi dengan media teknologi digital untuk proses produksi sampai pada promosi produk serta menemukan pasar yang potensial untuk hasil 
produksi UMKM. Dengan strategi bisnis online tersebut diharapkan dapat membantu mengatasi tantangan saat pandemi Covid-19.

Sumarni (2020) tentang media sosial dan E-commerce sebagai solusi tantangan pemasaran pada masa pandemi Covid-19. Dengan hasil penelitian yaitu selain tantangan yang dihadapi, banyak juga peluang dan startegi baru yang dihadapi oleh pelaku UMKM, seperti produksi, pemasaran, transaksi melalui via online. Pelaku usaha banyak berkolaborasi dengan platform yang tersedia untuk pemasaran dan hingga transaksi menggunakan jasa transportasi online. Dengan harapan dapat meningkatkan penjualan di masa pandemi Covid-19.

Anugrah (2020) tentang efektifitas penerapan strategi online marketing oleh UMKM dalam masa pembatasan sosial besar (PSBB) corona viruses disease 2019 (Covid-19). Hasilnya yaitu para pelaku bisnis UMKM mengalami masalah tersendiri untuk menjual produk saat diberlakukannya PSBB. Namun dengan adanya pemasaran online melalui aplikasi android dapat memudahkan para pelaku UMKM untuk mencapai target pasar yang telah di tentukan. Dengan di sediakannya program tersebut diharapkan dapat membawa dampak eknomi yang positif.

Dari pernyataan tersebut, dapat kita simpulkan bahwa dengan pemanfaatan penjualan online akan sangat membantu para pelaku UMKM menghadapi berbagai tantangan saat di masa pandemi Covid-19 ini. Dan tujuan penulis dalam penyusunan artikel penelitian yakni untuk melihat pengaruh dari penjualan online di masa pandemi Covid-19 terhadap omzet UMKM dengan studi kasus pada UKM Salad Nyoo Timoho Yogyakarta.

\section{LANDASAN TEORI}

Tahun 2008 tentang Usaha Mikro, Kecil, dan Menengah (UMKM), UMKM didefinisikan sebagai berikut:

1. Dalam Undang-Undang ini usaha mikro merupakan usaha produktif milik perorangan dan/atau badan usaha perorangan yang telah memenuhi kriteria Usaha Mikro.

2. Usaha Kecil merupakan usaha yang berdiri sendiri, atau badan usaha yang bukan merupakan anak perusahaan yang dikelola oleh perorangan atau bukan cabang perusahaan yang dimiliki, dikuasai, atau menjadi bagian baik langsung maupun tidak langsung dari Usaha Menengah atau Usaha Besar dan memenuhi kriteria Usaha Kecil sebagaimana yang tercantum dalam Undang-Undang tersebut.

3. Yang tercantum dalam undang-undang ini yang dimaksud usaha Menengah adalah usaha ekonomi produktif yang berdiri sendiri, yang dilakukan oleh orang perorangan cabang perusahaan yang dimiliki, atau dikuasai, baik langsung maupun tidak langsung dengan Usaha Kecil atau Usaha Besar dengan jumlah kekayaan bersih atau hasil penjualan tahunan (Sudati, 2019).

Pada Pasal 19 UU No. 20 Tahun 2008 tentang UMKM, dalam Pasal 16 ayat (1) huruf c pengembangan dalam bidang sumber daya manusia dilakukan dengan cara:

1. memberdayakan kewirausahaan.

2. meningkatkan keterampilan secara teknis agar suatu usaha bisa berkembang dengan baik.

3. Membuat pelatihan tentang UMKM agar bisa motivasi kreativitas bisnis, dan penciptaan wirausaha baru (Feni Dwi Anggraeni \& Hayat, 2018).

Dilihat dari karakteristiknya UMKM antara lain: 
1. Tidak adanya pembagian tugas yang jelas pada bidangnya, biasanya pemilik usaha merenangkap tugas dalam pengoperasian

2. Rendahnya akses industri kepada kredit formal, sehingga modal usaha mereka kebanyakan murni dari modal pribadi maupun kerabat keluarga.

3. Usaha kecil sebagian besar belum mempunyai izin badan hukum.

4. UMKM sebagian besar bergerak pada usaha minuman, makanan dan tembakau.

\section{METODELOGI PENELTIAN}

Pengumpulan informasi/data dilakukan di UMKM Salad Nyoo Timoho Yogyakarta. Dan untuk Jenis Penelitian Metode penelitian yang digunakan pada penelitian ini adalah metode deskriptif kualitatif dan untuk analisis data peneliti juga melakukan analisis SWOT (Strengths, Weakness, Opportunities and Threats), Analisis ini mengidentifikasi berbagai faktor secara sistematik untuk merumuskan strategi dari usaha. Analisis ini melihat bagaimana bisnis memaksimalkan kekuatan (strengths) dan peluang (opportunities), namun secara bersamaan juga dapat meminimalkan kelemahan (weaknesses) dan ancaman (threats).

Peneliti mengumpulkan dan mendeskripsikan seberapa besar Pengaruh penjualan online terhadap UKM Salad Nyo Timoho Yogyakarta yang terjadi ditengah pandemi Covid-19 dan bagaimana cara menghadapi dampaknya terhadap bisnis UKM. Untuk mendapatkan data primer peneliti melakukan wawancara serta dokumentasi dengan pelaku usaha UKM Salad Nyoo Timoho. Selain itu, karena keterbatasan waktu dan materi terkait penelitian ini, data sekunder peneliti mencari jurnal yang ada pada website. Kerangka pikiran penelitian dapat dilihat berikut ini:

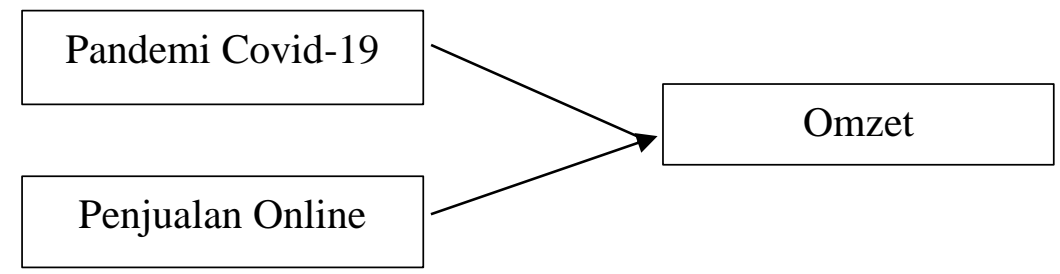

Gambar 1. Kerangka pemikiran

\section{HASIL PENELITIAN DAN PEMBAHASAN}

Yolanda Agatha merupakan owner juga founder dari Salad Nyoo, Berawal dari koskosan dengan modal hanya Rp 200.000, Salad Nyoo berkembang dan mendapatkan hati masyarakat sekitar, yang awalnya produk Salad Buah tidak dikenal dan akhirnya menjadi lifestyle healthy food sampai saat ini. Berbekal resep saus salad yang diracik sendiri dan penggunaan buah pilihan, penjualan salad rumahan ini, mendapat banyak tanggapan yang sangat baik dari konsumen. Dengan meningkatnya peminat Salad Nyoo di Yogyakarta, owner mulai secara perlahan berani untuk membuka 1 kedai kecil di Yogyakarta dan hingga sekarang berkembang menjadi 14 cabang di 4 kota (Yogyakarta, Solo, Semarang, dan Pontianak). Perjalanan 2 tahun dari 2018 sampai 2020 telah membawa Salad Nyoo mendapatkan beberapa penghargaan, mulai dari zero to hero Grabfood, UMKM terbaik Gofood dan beberapa penghargaan nasional lainnya.

Berdasarkan wawancara secara langsung kepada pelaku usaha UKM Salad Nyoo Timoho, menyatakan bahwa saat pandemi Covid-19 penjualan Salad Nyoo itu cukup 
tertantang yaitu omzet usaha ini sendiri menurun saat awal pandemi Covid-19, bisa dilihat pada tabel dan grafik. namun seiring berjalannya waktu dan hingga saat ini sudah mulai cukup stabil.

\begin{tabular}{|l|c|c|}
\hline \multicolumn{1}{|c|}{ Pos Laba Rugi } & Mei - Des 2019 & Jan - Mei 2020 \\
\hline Penjualan & 2.321 .803 .541 & 1.458 .167 .336 \\
\hline Harga Pokok Penjualan (HPP) & 951.939 .452 & 587.051 .239 \\
\hline Laba Kotor & 1.369 .864 .089 & 871.116 .097 \\
\hline $\begin{array}{l}\text { Beban Penjualan \& Adm. } \\
\text { Umum (SGA) }\end{array}$ & 374.233 .970 & 411.906 .105 \\
\hline Keuntungan Operasional & 995.630 .119 & 459.209 .992 \\
\hline Pendapatan (Beban) Lainnya & & 459.209 .992 \\
\hline Laba Usaha & 995.630 .119 & \\
\hline
\end{tabular}

Gambar 2. Bagan Profit Salad Nyoo 2019-2020. Sumber: Prospektus Salad Nyoo 2020.

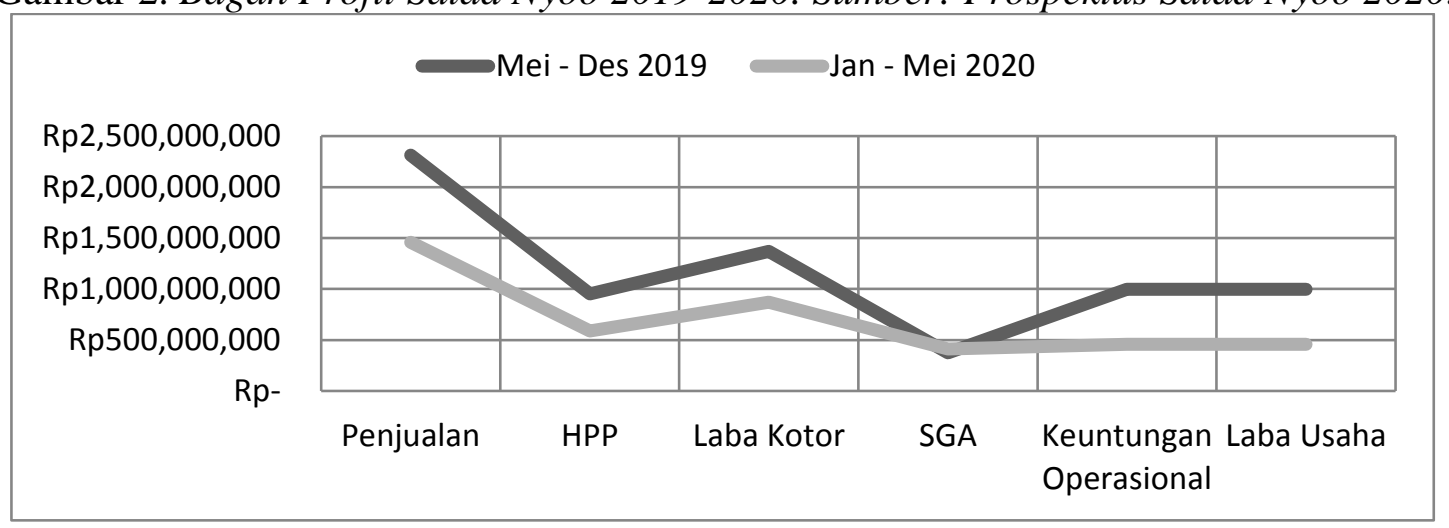

Gambar 3. Grafik Profit Salad Nyoo 2019-2020.

Dengan pemanfaatan teknologi digital para pelaku UMKM diberi dampak yang besar untuk membantu mendapatkan konsumen di kala pandemi Covid-19. Pelaku bisnis harus bisa melakukan penyesuaian dengan cepat, dari hal strategi hingga tujuan. Salad sendiri merupakan menu yang sehat, karena sehat inilah, maka saat penjualan tidak offline pun, banyak peminat dari konsumen untuk membeli melalui marketplace yang tersedia, seperti Grab food maupun Gofood.

Hasil dari penjualan online yang dilakukan cukup meningkat karena sering mengadakan promo yang gencar melalui promo online, seperti sekarang ini Salad Nyoo sedang promo buy 1 get 2 jadi konsumen bisa membawa pulang 3 salad. Selain itu, strategi penjualan perusahaan yang lain adalah dengan melakukan promo bundling dengan produk nasional seperti es krim AICE dan tolak angin. Hal ini terbukti cukup menarik minat customer untuk mencoba, yang berdampak pada kenaikan penjualan.

Perumusan strategi diterapkan melalui identifikasi dan analisis faktor-faktor eksternal yang terdiri dari peluang dan ancaman, serta faktor-faktor internal yang terdiri dari kekuatan dan kelemahan. Maka hasil analisis SWOT (Strengths, Weakness, Opportunities and Threats) yaitu: 
1. Strengths (Kekuatan)

Citra yang baik dan kualitas yang terjaga karena penggunaan bahan baku yang sehat yaitu dari buah-buahan sehingga sangat di gandrungi di masa pandemi, memiliki harga yang cukup terjangkau, memiliki banyak varian salad sehingga konsumen tidak bosan karena banyak pilihan, segmentasi pasar yang luas dengan pemanfaatan social media sebagai sarana pemasaran produk.

2. Weakness (Kelemahan)

Semakin banyak produk yang sama ataupun serupa sehingga harus lebih inovatif dan kreatif serta berani dalam berkembang.

3. Opportunities (Peluang)

Gencar melakukan promosi penjualan online melalui marketplace yang tersedia yaitu grabfood dan gofood serta promosi ke social media.

4. Threats (Ancaman)

Harus mampu menjaga kualitas dan cita rasa dari varian setiap produk agar konsumen bisa menetap dan tidak di ambil oleh kompetitor. Salah satunya dengan mengolah bahan baku dengan baik dan benar karena bahan seperti buah-buahan memiliki keawetan dan kesegaran masing-masing.

\section{KESIMPULAN}

Pandemi Covid-19 memang memiliki pengaruh bagi banyak orang. Di Indonesia, berdampak pada dalam sektor ekonomi terutama pada banyak UMKM. Dari para pelaku UMKM banyak merasakan dampak langsung berupa penurunan omzet penjualan akibat dari himbauan pemerintah kepada masyarakat agar untuk tetap di rumah saja sehingga cukup banyak UMKM yang harus berhenti beroperasi. Khususnya industri makanan dan minuman tidak lepas dari pengaruh tersebut. Penjualan online saat pandemi Covid-19 sangat berpengaruh terhadap omzet penjualan Salad Nyoo Timoho, yaitu terjadi penurunan yang cukup siginifikan saat awal pandemi, meskipun seperti itu, UMKM genjar melakukan penjualan online hingga saat ini dapat stabil kembali. Kolaborasi oleh UMKM dengan bekerja sama dengan platform, marketplace dan media social sangat membantu sebagai media pemasaran, promosi dan penjualan online. Dengan terus melakukan penjualan melalui platform yang tersedia karena banyak konsumen yang beralih ke belanja online dan tentu ini dapat menjangkau banyak konsumen juga mengadakan promo untuk kepuasan pelanggan serta mengembangkan produk dengan inovatif dan kreatif, tentunya para konsumen akan terus bertahan dengan Salad Nyoo. Dan dengan menjaga kualitas serta citra produk juga harus sangat di perhatikan dan ditingkatkan.

\section{DAFTAR PUSTAKA}

\section{Rosita, R. (2020). PENGARUH PANDEMI COVID-19 TERHADAP UMKM DI}

INDONESIA. JURNAL LENTERA BISNIS, 9(2), 109.

https://doi.org/10.34127/jrlab.v9i2.380

Hardilawati, W. laura. (2020). Strategi Bertahan UMKM di Tengah Pandemi Covid-19. Jurnal Akuntansi dan Ekonomika, 10(1), 89-98.

https://doi.org/10.37859/jae.v10i1.1934 
Rizal, M., Maulina, E., \& Kostini, N. (2019). FINTECH SEBAGAI SALAH SATU SOLUSI PEMBIAYAAN BAGI UMKM. AdBispreneur, 3(2), 89.

https://doi.org/10.24198/adbispreneur.v3i2.17836

Santoso, R. (2020). Review of Digital Marketing \& Business Sustainability of ECommerce During Pandemic Covid19 In Indonesia. Jurnal Ilmu Ekonomi Terapan, 5, 13.

Anugrah, R. J. (2020). Efektifitas Penerapan Strategi Online Marketing Oleh UMKM Dalam Masa Pembatasan Sosial Berskala Besar (PSBB) Corona Viruses Disease 2019 (Covid-19). Jurnal Manajemen dan Inovasi (MANOVA), 3(2), 55-65. https://doi.org/10.15642/manova.v3i2.302

Thaha, A. F., \& Hasanuddin, U. (t.t.). DAMPAK COVID-19 TERHADAP UMKM DI INDONESIA. JURNAL BRAND, $2,7$.

Sumarni, T., \& Melinda, L. D. (2020). Media Sosial dan E-commerce sebagai Solusi Tantangan Pemasaran Pada Masa Pandemi Covid-19 (Studi Kasus: UMKM Warung Salapan). ATRABIS: Jurnal Administrasi Bisnis (e-Journal), 6(2), 9. https://doi.org/10.38204/atrabis.v6i2.489

Komalasari, R. (2020). MANFAAT TEKNOLOGI INFORMASI DAN KOMUNIKASI DI MASA PANDEMI COVID 19. TEMATIK, 7(1), 38-50.

https://doi.org/10.38204/tematik.v7i1.369

Ningtyas, P. K., \& Sunarko, B. (2015). ANALISIS FAKTOR YANG MEMPENGARUHI ADOPSI E-COMMERCE DAN PENGARUHNYA TERHADAP KINERJA UMKM. 2l(1), 13.

Shaferi, I., Nawarini, A. T., \& Dewi, M. K. (2017). PEMANFAATAN TEKHNOLOGI DALAM UPAYA MENINGKATKAN PRODUKTIVITAS USAHA KECIL. Performance, 23(1), 11. https://doi.org/10.20884/1.performance.2016.23.1.288 